\title{
Response of bankfull discharge of the Inner Mongolia Yellow River to flow and sediment factors
}

\author{
Suzhen Hou, Ping Wang*, Yan Guo and Ting Li \\ Yellow River Institute of Hydraulic Research, YRCC, Zhengzhou 450 003, China. \\ ${ }^{*}$ Corresponding author.e-mail: wp_sc@sina.com
}

Bankfull discharge is a comprehensive factor reflecting the channel-forming capability of water flow and the flood and sediment transport capacity of a river channel. It is based on the interaction of the flow, sediment, and river channel, of which flow and sediment conditions play crucial roles. Using data recorded since the 1950s, this paper analyses statistically, the characteristics and variations of bankfull discharge at two stations on the Inner Mongolian reaches of the upper Yellow River. Results indicate that flood season variations in bankfull discharge are nonlinear and are governed by flood peak discharge, mean discharge, and the mean incoming sediment coefficients. Variation in bankfull discharge is related not only to the flow and sediment conditions of the current year but also to those of previous years. The 10-year moving average of flow and sediment conditions can be representative of present and previous years. By considering flood season peak discharge and incoming sediment coefficients as independent impact factors, a formula is derived to determine bankfull discharge. The results can be used to predict the bankfull discharge of the Yellow River channel in Inner Mongolia under specific flow and sediment conditions and provide reference for the purpose of further study related to restoring and maintaining the basic functions of the river channel regarding flood discharge and sediments.

\section{Introduction}

Bankfull discharge refers to river discharge when the water level is coincident with the top of the riverbank (Williams 1978; Knighton 1996). The corresponding water flow has high velocity and displays strong sediment transport and channelforming capabilities (Leopold and Maddock 1953; Nolan et al. 1987; Knighton 1996), therefore, it is equated with channel-forming discharge under certain conditions (Qian et al. 1987; Rosgen 1994). Bankfull discharge is an important index reflecting sediment transport and channel-forming capabilities and thus, it is a crucial element of research in riverbed evolution. It is well known that riverbed evolution is caused by non-equilibrium sediment transport resulting from the interaction between the flow and the river channel. Of the two factors, the sediment-laden flow is decisive (Petts 1984; Williams and Wolman 1984; Collier et al. 1996; Petts and Gurnell 2005). Thus, as an important index of the flow capacity of a channel, bankfull discharge is definitely influenced by incoming water and sediment conditions.

Present studies on bankfull discharge can be divided into three groups (Wu et al. 2008): the calculation of bankfull discharge (Biedenharn et al. 2001), the relationship between bankfull discharge and channel-forming discharge (Lee and Julien 2006) and the relationship between bankfull discharge and different influencing factors. This paper addresses the third topic. Despite the complex impact of factors such as climate, riverbed conditions, sediment particle sizes and human activities,

Keywords. Yellow River; Inner Mongolia; bankfull discharge; flood peak discharge; incoming sediment coefficient. 
many previous researchers have established a relation between bankfull discharge and the drainage area. However, the correlation indices given by various researchers are different and vary from 0.50 to 0.95 (McCandless 2003). Qian et al. (1972) believe that bankfull discharge is related to the average long-term discharge that occurs over many years. This leads to the concept that the current channel shape is the result of the cumulative effect of discharge over many years. Qian et al. (1989) presented a relationship between bankfull discharge and peak flow in a chart of sediment discharge against corresponding flow rates at all levels. The relation is actually an expression of the geomorphic work curve proposed by Wolman and Miller (1960). Lin et al. (2005) conducted research on the response of bankfull discharge from incoming water and sediments at the Huaxian hydrologic station on the Weihe River. They observed that bankfull discharge responds better when the 2-year moving average annual runoff and flood-season runoff are used. Tayfur and Singh (2011) studied methods that calculate bankfull discharge based on the channel size. Hou and Wang (2005) analysed the bankfull discharge of the channel of the Inner Mongolian reaches of the Yellow River. They reached the conclusion that changes in bankfull discharge are related to the 5-year moving average of annual runoff, flood season runoff, flood peak discharge and flood volume. However, this research did not consider the effect of sediment, which is another important factor and there has been no further analysis to justify using the 5-year moving average. $\mathrm{Hu}$ et al. (2006) obtained a relation between the bankfull discharge of the lower Yellow River and the average annual runoff at Huayuankou and then analysed the response of bankfull discharge in the lower Yellow River to incoming water and sediment using mathematical models. Liu et al. (2006) believe that for non-overbank floods, the channelforming capabilities of floods in the lower Yellow River are related to the flood dynamic parameters, which comprise the flood volume and flood peak discharge. Research (Wu et al. 2007) conducted during the flood season on the lower reaches of the Yellow River have shown that bankfull discharge has a significant relationship with the 4-year moving average of discharge and to the 5 -year moving average of the incoming sediment coefficient. This implies that the water and sediment conditions of previous years impose a cumulative impact and lagged influence on future bankfull discharge. Furthermore, $\mathrm{Wu}$ (2008), also using the channel of the lower reaches of the Yellow River as the target of research, established a lagged response model to predict bankfull discharge according to the selfadjustment principle of riverbed evolution. In this model, the moving average of discharge and the moving average of incoming sediment coefficient of the flood season were combined as multiple factors.

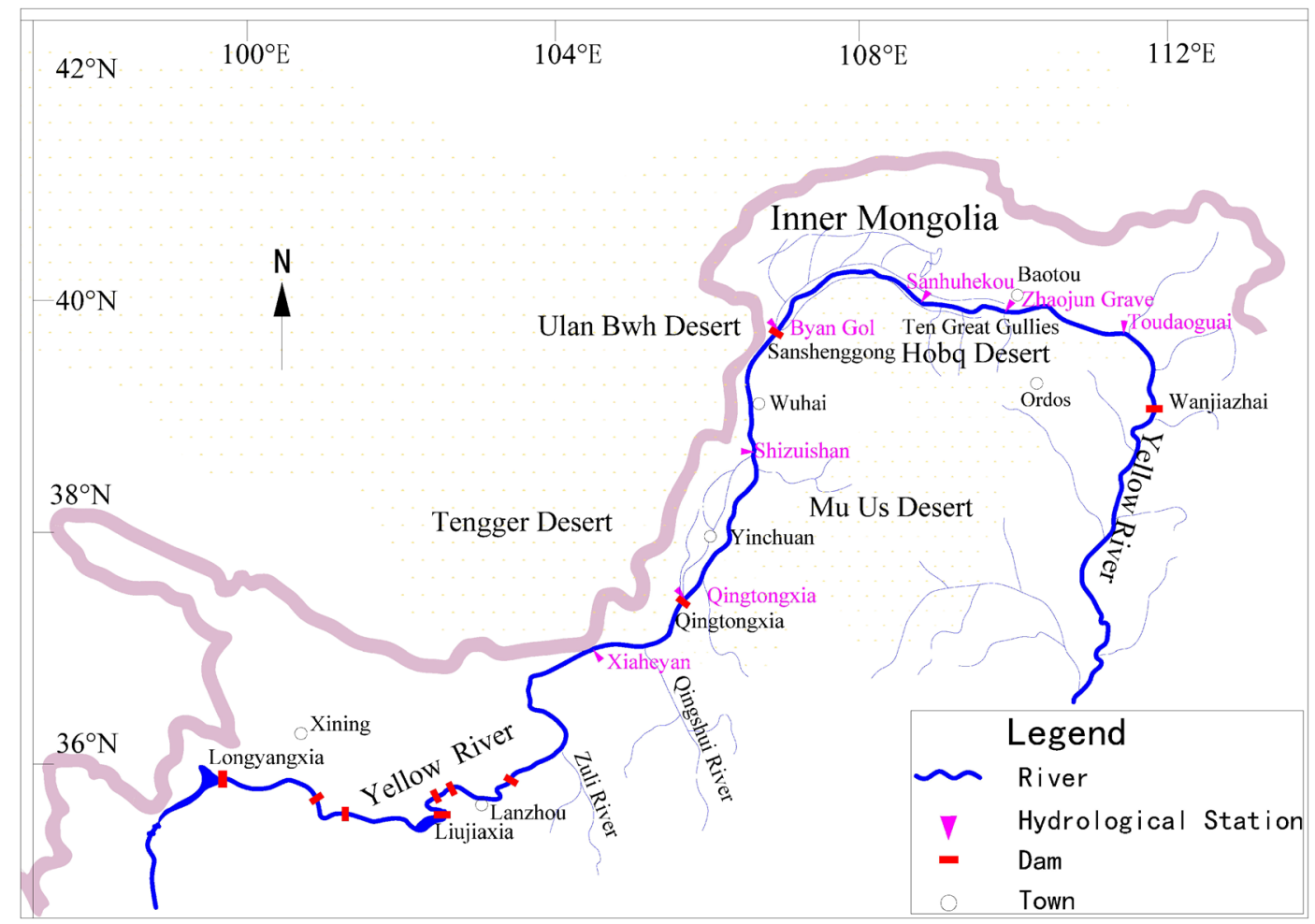

Figure 1. Positions of major reservoirs and hydrological stations from Longyangxia to Toudaoguai. 
The results from this model show that it would take approximately 5 years to reach a new balance after changes to the incoming water and sediment.

Based on accurate data from over 50 years and the self-adjustment principle of riverbeds, cross sections located at Bayangaole and Sanhuhekou stations on the Inner Mongolian reaches of the Yellow River were selected as the research objects (figure 1). Using regression analysis, the response relation between bankfull discharge and incoming water and sediment conditions are studied and a method for the calculation of bankfull discharge established. This provides a reference for further studies on how to restore and maintain the flood-carrying capacity and sediment transport capability of the channel.

\section{Study area}

The Yellow River has a total length of $5464 \mathrm{~km}$ and it is the second longest river in China. The main channel is divided into the upper, middle, and lower reaches according to geographic, geological, and hydrological conditions. This paper focuses on the lower part of the upper reaches in Inner Mongolia, the northernmost area of the Yellow River basin (figure 1). The channel within the region is $520-\mathrm{km}$ long, spanning from the Sanshenggong dam to Toudaoguai. The features of the channel are outlined in table 1 . The $220.7-\mathrm{km}$ channel from Sanshenggong to Sanhuhekou is a relatively straight channel comprising both wide and shallow cross sections and multiple sandbars. The average channel width is $3500 \mathrm{~m}$ with a stream gradient of $0.17 \%$. The channel from Sanhuhekou to Zhaojunfen is $126.4-\mathrm{km}$ long and is transitional with three mountain flood valleys along the southern bank. On average, the channel is approximately 4000-m wide with a stream gradient of $0.12 \%$. The channel from Zhaojunfen to Toudaoguai is 173.8-km long and exhibits a meandering pattern with varying channel widths of approximately 1200-5000 m and an average stream gradient of $0.1 \%$. There are three hydrological stations installed at Bayangaole, Sanhuhekou and Toudaoguai. The Bayangaole hydrological station is 400-m downstream from the Sanshenggong Dam. The Sanhuhekou hydrological station is located 221-km downstream from the Bayangaole hydrological station. It is the major method that is used for flood control in the Inner Mongolia region. The Toudaoguai hydrological station is located $300-\mathrm{km}$ downstream from the Sanhuhekou station and serves as the major turning point and control station for the water and as a location for the observation of sediment variation in the upper and middle reaches of the Yellow River.

Because the Inner Mongolian reaches of the Yellow River are located in an area of tectonic subsidence, it generally tends to be silted. The current flow route was stabilised only 200 years ago (Li et al. 2003). The rise of the riverbed is due to incoming sediment from branches of the upper reaches of the upper Yellow River, coarse sand that blew from the surrounding deserts into the Inner Mongolian reaches (Ta et al. 2008, 2011; Wang et al. 2010; Yao et al. 2011; Fan et al. 2012) and the water and sediment adjustment controlled by the dams in the upper reaches of the upper Yellow River (Shao and Wang 2002; Zhao et al. 2002; Shen et al. 2007; Qin et al. 2011; Ran et al. 2012; Wang et al. 2012). Since 1952, channel sediment has been increasing steadily and the channel was in a state of constant siltation from 1952 to 1967. However, from 1968 to 1986, the channel sediment was washed away. Then, after 1986, the sediment started building again at a steady rate, leading to both a reduction in the river's cross section and to a decrease in the discharge capacity of the river channel (figure 2).

The change in the channel of the Inner Mongolian reaches of the Yellow River has characteristics of scouring in high flow and deposition in low flow (Hou 1996). Since 1987, because of the regulation of Longyangxia Reservoir, the peak discharge, sediment transport, and flood-carrying

Table 1. Basic channel features of the Yellow River in Inner Mongolia.

\begin{tabular}{|c|c|c|c|c|c|c|}
\hline River section & River type & $\begin{array}{l}\text { River length } \\
(\mathrm{km})\end{array}$ & $\begin{array}{l}\text { Average river } \\
\text { width }(\mathrm{m})\end{array}$ & $\begin{array}{l}\text { Average width of } \\
\text { main channel }(\mathrm{m})\end{array}$ & $\begin{array}{l}\text { Gradient } \\
(\% 0)\end{array}$ & $\begin{array}{l}\text { Flexural } \\
\text { coefficient }\end{array}$ \\
\hline $\begin{array}{c}\text { Sanshenggong- } \\
\text { Sanhuhekou }\end{array}$ & Wandering & 221.5 & 3500 & 750 & 0.17 & 1.28 \\
\hline $\begin{array}{l}\text { Sanhuhekou-- } \\
\text { Zhaojunfen }\end{array}$ & Transitional & 125.9 & 4000 & 710 & 0.12 & 1.45 \\
\hline $\begin{array}{l}\text { Zhaojunfen-- } \\
\text { Toudaoguai }\end{array}$ & Meandering & 173.8 & $\begin{array}{l}\text { Upper reach: } 3000 \text {; } \\
\text { lower reach: } 2000\end{array}$ & 600 & 0.10 & 1.42 \\
\hline
\end{tabular}




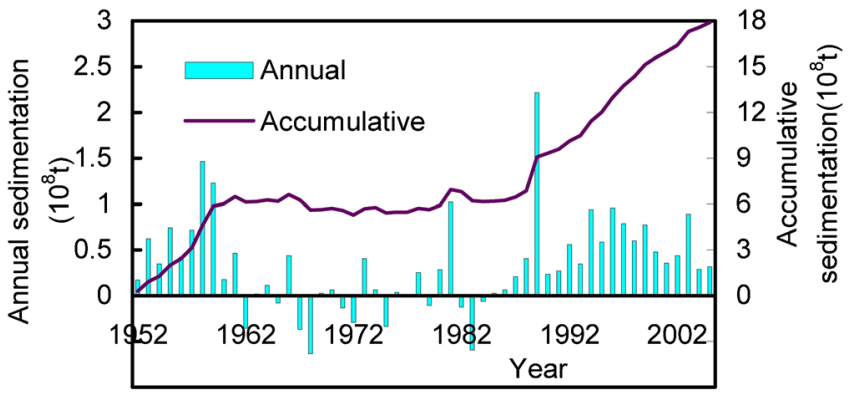

Figure 2. Variations in sedimentation accumulation in the channel from Bayangaole to Toudaoguai.

capacity have decreased and significant deposition has meant that the channel has shrunk. This has led to overbanking and the bursting of riverbanks at low flow, resulting in serious problems of ice and flood control in this section of the river. For example, on 5th September 2003, the flow of the main channel was measured as approximately only 1500 $\mathrm{m}^{3} / \mathrm{s}$, but water overflowed some parts of the floodplain between Sanhuhekou and Zhaojunfen, which resulted in burst dykes.

\section{Methodology}

An alluvial river is defined as one that is capable of adjusting itself to remain relatively balanced when incoming water and sediment pass through (Qian et al. 1987). In other words, when a change in incoming water and sediment conditions from the upper reaches occurs, or a change in the border conditions of the lower reaches takes place, a section of the river will establish a new balanced state that is adapted to the new water and sediment conditions through the adjustment of erosion or sedimentation. The adjustment of the riverbed results in changes to the channel's cross sections and therefore, to changes in the bankfull discharge, which is viewed as a comprehensive factor both reflecting changes of the channel cross sections and determining the flood discharge capacity of the channel. For an alluvial river, material forming the border conditions comprises deposited particles brought to a specific location by water flow over many years. Thus, any adjustment of the riverbed will not be completed immediately following changes in the water and sediment conditions but over a longer period, which is called the relaxation time (Brunsden 1980). Therefore, bankfull discharge is not only related to the flow and sediment conditions of the current year but also to those of previous years. In this paper, based on the principle of the self-adjustment of riverbeds, the relation between bankfull discharge and incoming water and sediment conditions of the Inner Mongolian reaches of the Yellow River is studied using the following data and methods.

\subsection{Data}

The data used in the analysis are mainly from two hydrological stations: Bayangaole and Sanhuhekou, which were established in 1947 and 1950, respectively. The data from the stations are provided by the Hydrological Bureau of the Yellow River Conservancy Commission and the measurements follow the technical standards issued by the Ministry of Water Resources of China. The measured variables are discharge, water level, suspended sediment concentration, water surface width, water depth, flow velocity, and cross section. The channel of the studied river reaches is composed of sand. Suspended sediment is the principal method of sediment transportation and plays a dominant role in the geomorphological processes. Therefore, bed load is not measured at these two hydrological stations. In the early years, measurements of some other variables such as the cross section were not performed, which are necessary for determining bankfull discharge. Thus, the discharge and sediment series adopted in the analysis are from 1947 to 2009 for Bayangaole and from 1950 to 2009 for Sanhuhekou (table 2). The adopted cross-section series are from 1958 to 2009 for Bayangaole and from 1959 to 2009 for Sanhuhekou (table 2).

\subsection{Determining historical bankfull discharge}

To determine the historical bankfull discharge, the first step is to obtain the bankfull level. Here, the bankfull level was considered equal to the bank top level identified from the graph of the cross section measured at the hydrological station. The Inner Mongolian reaches of the upper Yellow River studied here, usually exhibit a simple cross-section form composed of a single main channel and flood plains on both sides. The flood plain has a relatively even height and the banks on both sides are steep.

Table 2. Observed data of upper Yellow River.

\begin{tabular}{lll}
\hline Hydrological station & Bayangaole & Sanhuhekou \\
\hline Water and sediment & $1947-2009$ & $1950-2009$ \\
$\quad$ series & & \\
Cross section series & $1958-2009$ & $1959-2009$ \\
$\begin{array}{l}\text { Flood season mean } \\
\text { discharge } Q_{p} / \mathrm{m}^{3} \cdot \mathrm{s}^{-1}\end{array}$ & $284-2883$ & $355-2803$ \\
$\begin{array}{l}\text { Flood peak discharge } \\
Q_{m} / \mathrm{m}^{3} \cdot \mathrm{s}^{-1}\end{array}$ & $817-5210$ & $834-5460$ \\
$\begin{array}{l}\text { Incoming sediment } \\
\text { coefficient } \zeta / \mathrm{kg} \cdot \mathrm{s} \cdot \mathrm{m}^{-6}\end{array}$ & $0.0023-0.0437$ & $0.0029-0.0141$ \\
\hline
\end{tabular}


Therefore, on a graph of the cross section, there is a distinct break between the flood plain and the main channel. The level of the break point is considered as the bankfull level. The second step is to construct a water-level-discharge curve using measured daily mean discharge data and daily mean water-level data and then to find actual discharges or to interpolate discharges for water levels corresponding to the bankfull level from the curve. These discharges are the bankfull discharges. In this article, the bankfull discharge occurring in the post flood season was taken as the annual bankfull discharge, which is a value more persuasive for comparison.

\subsection{Establishment of the relation between bankfull discharge and impact factors}

Bankfull discharge is the result of interactions between the water and sediment conditions and the main channel section form. The water and sediment conditions are specified by factors that include the flood peak discharge, average discharge, sediment concentration, annual runoff, and incoming sediment coefficient. The incoming sediment coefficient is a compound factor (Yue 1995), which is expressed as follows:

$$
\zeta=S / Q
$$

where $\zeta\left(\mathrm{kg} \cdot \mathrm{s} \cdot \mathrm{m}^{-6}\right)$ is the moving average incoming sediment coefficient during the flood season, $S\left(\mathrm{~kg} / \mathrm{m}^{3}\right)$ represents the concentration of the suspended sediment and $Q\left(\mathrm{~m}^{3} / \mathrm{s}\right)$ represents the discharge. The incoming sediment coefficient reflects the magnitude of sediment concentration transported by unit discharge. The riverbed may become silted when the incoming sediment coefficient is large, and washed when it is small. As an empirical factor, the incoming sediment coefficient is applied widely in studies on the riverbed evolution of the Yellow River (Xu 2004; Hu 2005; $\mathrm{Wu}$ and Zhang 2007). Among the above factors, flood peak discharge, average discharge, and the incoming sediment coefficient were chosen as the principal factors for the analysis. Because channel adjustments usually occur during the flood season, due to an increase in discharge, one of the three selected factors, the average discharge, should be the average discharge of the flood season. Furthermore, the incoming sediment coefficient should be that of the flood season, expressed as:

$$
\zeta=\bar{S} / \bar{Q}
$$

where $\bar{S}\left(\mathrm{~kg} / \mathrm{m}^{3}\right)$ represents the mean concentration of the suspended sediment of the flood season and $\bar{Q}\left(\mathrm{~m}^{3} / \mathrm{s}\right)$ represents the mean discharge of the flood season.
The relations between bankfull discharge and each impact factor are established and the correlations validated using the $t$-test method, after transforming the bankfull discharge and the impact factors into linear relationships. Furthermore, to determine the duration of the cumulative impact of each factor on bankfull discharge, the correlations between bankfull discharge and the moving average value of the factors of previous years was tested by regression analysis.

The relation between bankfull discharge and the multi-factors is then constructed. The moving average of the incoming sediment coefficient $\zeta_{n}$ is selected as one of the multi-factors. One of the two discharge factors: the moving average of flood peak discharge $Q_{m n}$ and the mean discharge of the flood season $\bar{Q}_{n}$, is chosen as another of the multi-factors based on the single factor regression analysis. The subscript $n$ means the correlation coefficient is a maximum after $n$ years' moving average, which indicates that the main channel section has reached a new equilibrium state after undergoing $n$ years of adjustment processes, following the change in the incoming water and sediment conditions. The formula for bankfull discharge is expressed as follows:

$$
Q_{b}=k Q^{\alpha} \zeta_{n}^{\beta},
$$

where $Q_{b}\left(\mathrm{~m}^{3} / \mathrm{s}\right)$ is the bankfull discharge, $Q\left(\mathrm{~m}^{3} / \mathrm{s}\right)$ is the discharge factor, which could be $Q_{m n}$ or $\bar{Q}_{n}$. $k, \alpha$ and $\beta$ are constants, which are determined by regression analysis.

\section{Results and discussion}

\subsection{Variation characteristics of bankfull discharge of the Inner Mongolian reaches of the Yellow River}

Variations in bankfull discharge at the Bayangaole and Sanhuhekou stations for each year are shown in figure 3. Before 1990, bankfull discharge at Bayangaole varied from $4000-6000 \mathrm{~m}^{3} / \mathrm{s}$ with small fluctuations in the 1970s and early 1980s. Following the initial use of the Longyangxia Reservoir in October 1986, the discharge has been reduced dramatically, resulting in an imbalance of water and sediment. This imbalance caused siltation of the riverbed and started a trend of decreasing bankfull discharge. Bankfull discharge at Sanhuehkou dropped to a historical minimum of $1300 \mathrm{~m}^{3} / \mathrm{s}$ in 2004 but subsequently, began to rise slowly.

Prior to 1968, bankfull discharge at Sanhuhekou varied from 3100-4200 m³/s. After 1968, the Liujiaxia and Qingtongxia Reservoirs were implemented as the primary means by which to block floods and sediment from adjacent branch rivers. This 


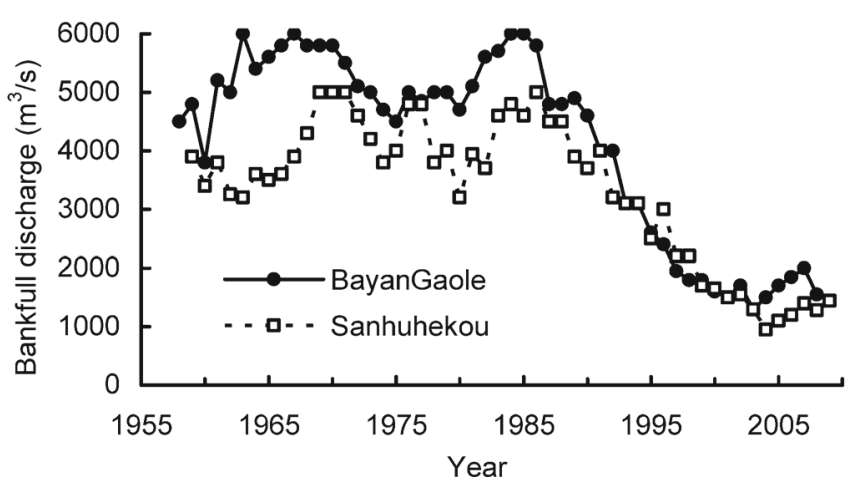

Figure 3. Variation in bankfull discharge for each year.

decreased the sediment concentration entering the Inner Mongolian reaches of the Yellow River, resulting in scouring of the riverbed. Bankfull discharge from 1968 to 1986 was significant with a maximum in excess of $5000 \mathrm{~m}^{3} / \mathrm{s}$. As the Longyangxia Reservoir began to store water in 1986, the flow process dropped dramatically and because the channel-forming capacity of the flow was weakened, there was serious siltation of the channel. Bankfull discharge continued to decline until 2004 when the discharge was measured at $1000 \mathrm{~m}^{3} / \mathrm{s}$. However, after that year, bankfull discharge began to rise slowly.

\subsection{Relationships between bankfull discharge and each principal affecting factor}

The relationship between bankfull discharge and the average discharge during the flood season at Bayangaole station is plotted in figure 4(a). It demonstrates that bankfull discharge increases in conjunction with growth in the average discharge of the flood season. Flooding is the principal force that contributes to the evolution of river channels. Flood peak discharge is the most important factor when analysing floods. It determines the degree of adjustment that a river will experience over a short period (Qian et al. 1987). The relationship between bankfull discharge and flood peak discharge was established, as shown in figure 4(b). It indicates that bankfull discharge increases in conjunction with flood peak discharge. Figure 4(c) displays the nonlinear relation between bankfull discharge and the average incoming sediment coefficient of the flood season. This relationship indicates that bankfull discharge is reduced as the incoming sediment coefficient increases. In summary, the regression analysis based on over 50 years' data shows that bankfull discharge is nonlinearly related to the average discharge of the flood season, flood peak discharge, and incoming sediment coefficient with a correlation coefficient $|R|$ ranging from 0.65 to 0.75 .
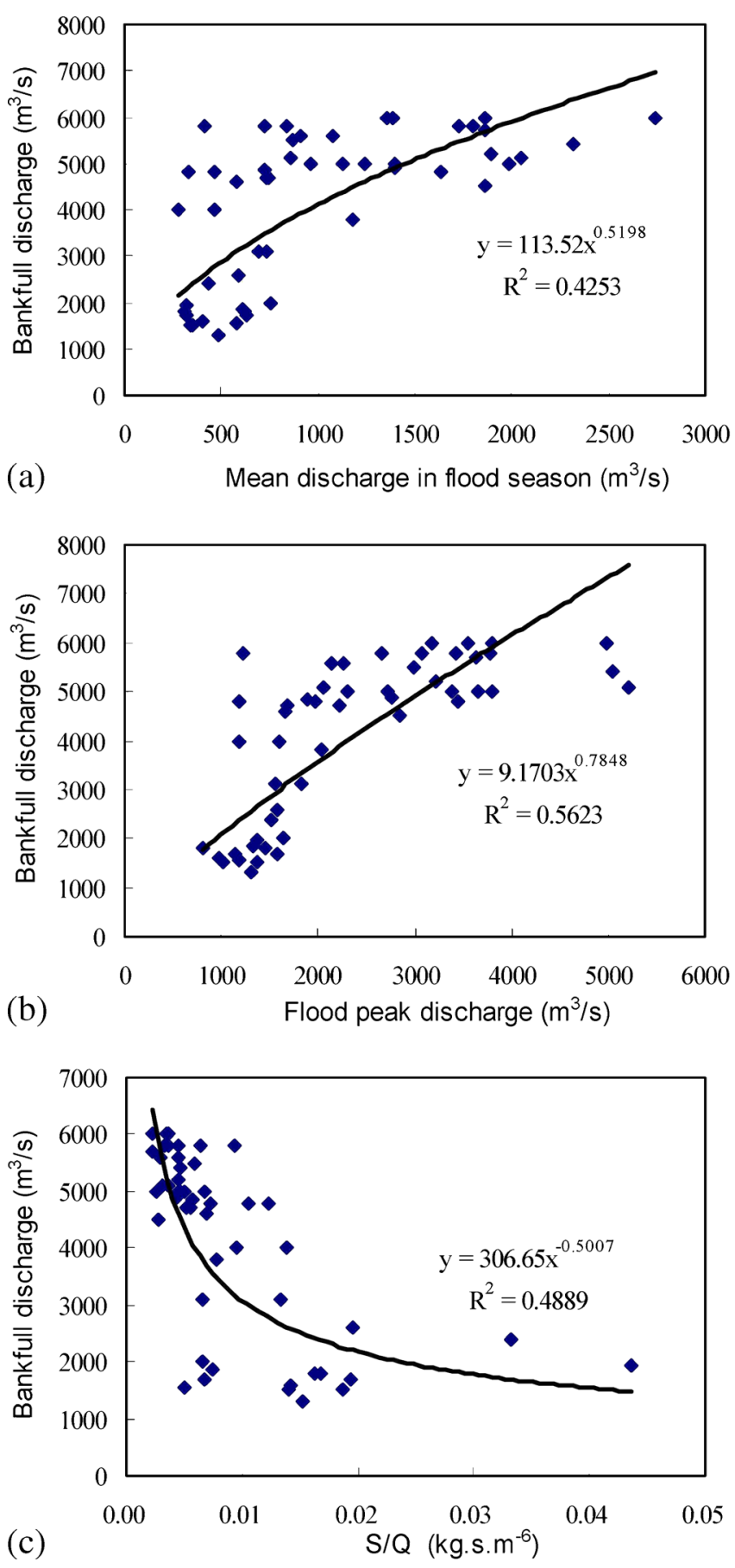

Figure 4. Relationship between bankfull discharge and (a) mean discharge during flood season, (b) peak discharge and (c) incoming sediment coefficient $S / Q$ at Bayangaole.

The correlations between bankfull discharge and its influencing factors are validated using the $t$-test method, after transforming the discharge and the influencing factors into linear relationships. If the significance level $\alpha=0.05$, then $t_{\alpha / 2}(50-2)=2.01$ and the calculated results based on $t=\frac{R \sqrt{n-2}}{\sqrt{1-R^{2}}}$ are displayed in table 3 . For a significance level of $\alpha=0.05,|t|>t_{\alpha / 2}$ and a correlation coefficient that conforms to the significance level, indicates 
Table 3. Bankfull discharge correlation and assumption check at Bayangaole.

\begin{tabular}{llll}
\hline Data & $\begin{array}{c}\text { Flood-season } \\
\text { average } \\
\text { flow } Q_{p}\end{array}$ & $\begin{array}{c}\text { Flood } \\
\text { peak flow } \\
Q_{m}\end{array}$ & $\begin{array}{c}\text { Incoming } \\
\text { sediment } \\
\text { coefficient } S / Q\end{array}$ \\
\hline$|t|$ & 7.77 & 11.87 & 9.48 \\
Significance F & $2.6 \times 10^{-7}$ & $3.7 \times 10^{-10}$ & $1.6 \times 10^{-8}$ \\
$|R|$ & 0.65 & 0.75 & 0.70 \\
\hline
\end{tabular}

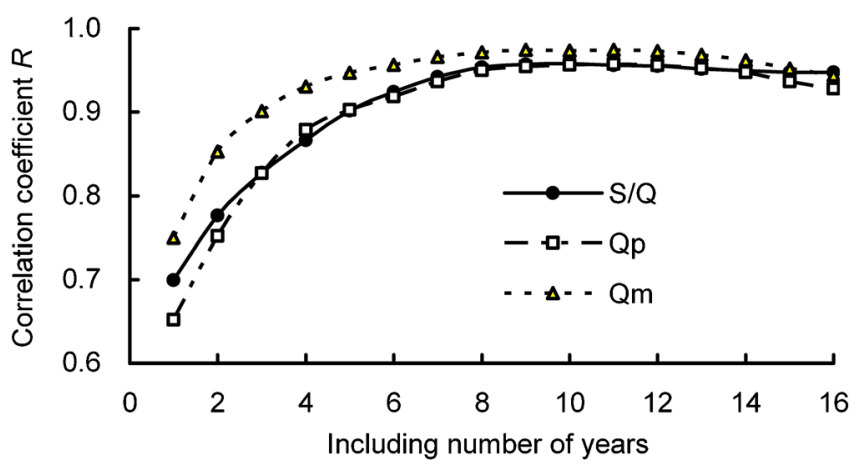

Figure 5. Changes in the correlation degree between bankfull discharge and the moving average flow and sediment factors within a given time frame at Bayangaole.

that bankfull discharge is indeed correlated with the mentioned factors but not to a significant degree.

From the regression analysis for bankfull discharge and the impact factors at Bayangaole, figure 5 shows that the correlation coefficients grow as the number of years included increases. The correlation coefficients grow the fastest from 1 to 4 years, reaching a maximum at approximately 10 years, for which the correlation coefficients are usually greater than 0.95 . After 10 years, the correlation coefficients decrease with any further increase in the number of years included. This observation indicates that the 10-year moving averages of water and sediment data reflect the cumulative impact of incoming water and sediment conditions, while also showing that the impacts of conditions from more than 10 years before have disappeared.

Similarly, the regression analysis produces correlations between bankfull discharge and the impact factors of moving averages from a varying number of years at Sanhuhekou (figure 6). The results show that the correlation coefficient of bankfull discharge and the incoming sediment coefficient increases as the number of included years increases. It is shown that the largest coefficient is achieved when 10 years' data are included and that the degree of correlation decreases as the number of years included increases. However, the correlation coefficients from flood peak discharge and the average discharge of the flood season both increase significantly when the number of years included does

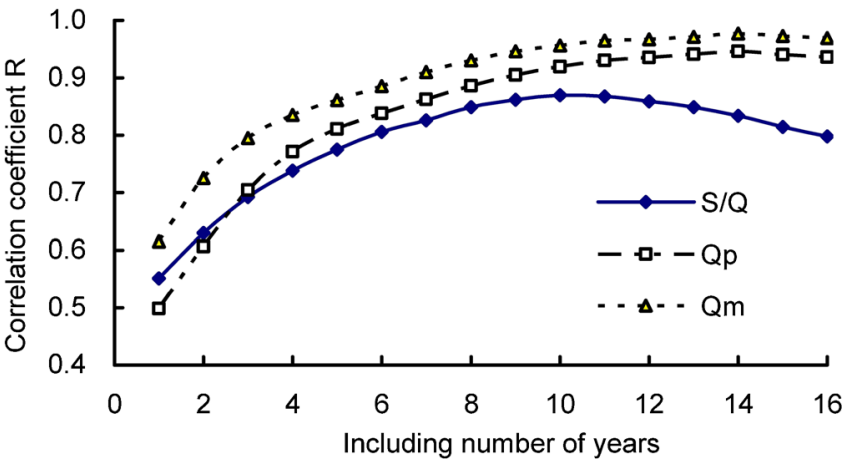

Figure 6. Changes in the correlation degree between bankfull discharge and the moving average water and sediment factors within a given time frame at Sanhuhekou.

not exceed 10. After 10 years, the coefficients continue to increase slightly, reaching a maximum at 14 years. Ignoring the slight difference between the correlation coefficients of 10 and 14 years for the flood peak discharge and the average discharge of the flood season, the impact of all water and sediment conditions can be considered the greatest at approximately 10 years and that the influence of conditions from more than 10 years earlier are small.

\subsection{Relationships between bankfull discharge and multi-affecting factors}

Single factor analysis shows that bankfull discharge is responsive to the average discharge of the flood season, flood peak discharge, and incoming sediment coefficient. The correlation with flood peak discharge is the most significant. For Bayangaole station, the correlations of bankfull discharge with the average discharge of the flood season and with incoming sediment coefficient are very similar when the number of years included is the same. At Sanhuhekou Station, the correlation with incoming sediment coefficient is weakest and the correlation with the average discharge of the flood season is intermediate. When the number of years included for the moving average is 10 , the correlations of bankfull discharge and the factors for both Bayangaole and Sanhuhekou stations are almost the highest. Therefore, the 10-year condition can reflect the influence of the current year and previous years and thus, a bankfull discharge formula based on data for the 10-year moving average of water and sediment factors is established.

Among the above-mentioned factors, flood peak discharge, which reflects the capacity of a flood to form a riverbed, is important in the flow dynamics. It is a factor sensitive to short-term adjustments in the riverbed, which results in the riverbed being adjusted in a nonlinear way (Zhang et al. 2002). The average discharge during the flood season and 
the flood peak discharge in the upper reaches of the Yellow River are closely related (figure 7). Therefore, the 10-year moving average flood peak discharge and the 10-year moving average incoming sediment coefficient are selected as independent influencing factors for the multi-factor regression analysis.

The results of the analysis produce expressions of bankfull discharge at the two cross sections. The formula for Bayangaole is:

$$
Q_{b}=0.1458 Q_{m 10}^{0.8925} \zeta_{10}^{-0.3341}
$$

and the formula for Sanhuhekou is:

$$
Q_{b}=0.1458 Q_{m 10}^{1.0238} \zeta_{10}^{-0.3909}
$$

where $Q_{m 10}$ is the 10-year moving average flood peak discharge and $\zeta_{10}$ is the 10-year moving average incoming sediment coefficient of the flood season. The ranges of the data are shown in table 2. The relations between historical bankfull discharges and the calculated values are given in figures 8 and 9 . There is good agreement between historical bankfull discharge and the calculated values. The largest error is $25 \%$ and averages $7.2 \%$ at the Bayangaole station and at the Sanhuhekou station, the largest error is $13 \%$ with an average of $2.9 \%$.

The expressions above reflect quantitatively the relations between bankfull discharge and the combination of flood peak discharge and the incoming sediment coefficient. This indicates the impact of water and sediment conditions of the current year and the lagged impact of the previous years. The coefficients and indices in the formulas for the two stations are different because of changes in water and sediment conditions along the channel and the border conditions of the riverbed. Because differences in water and sediment conditions influence channel evolution of the Inner Mongolian reaches of the upper Yellow River and the lower Yellow River (Wang et al. 1999; Shen et al. 2000), the number of years of continuous influence upon channel

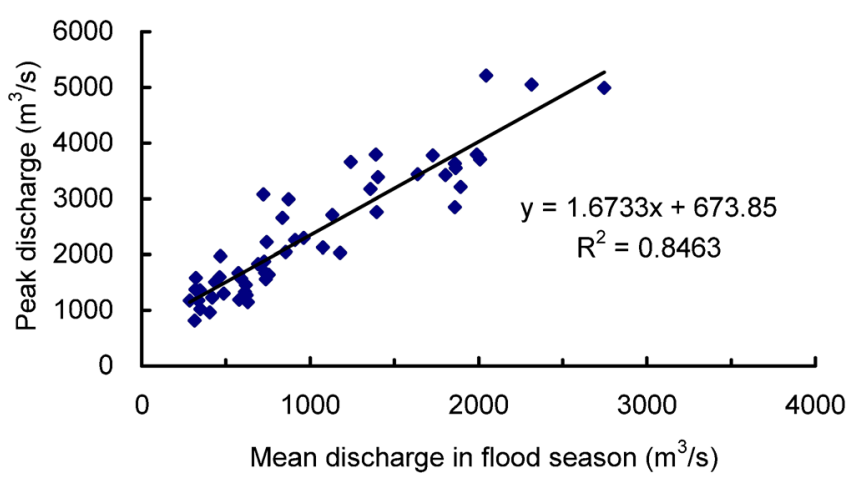

Figure 7. Correlation between flood peak discharge and average discharge of the flood season.

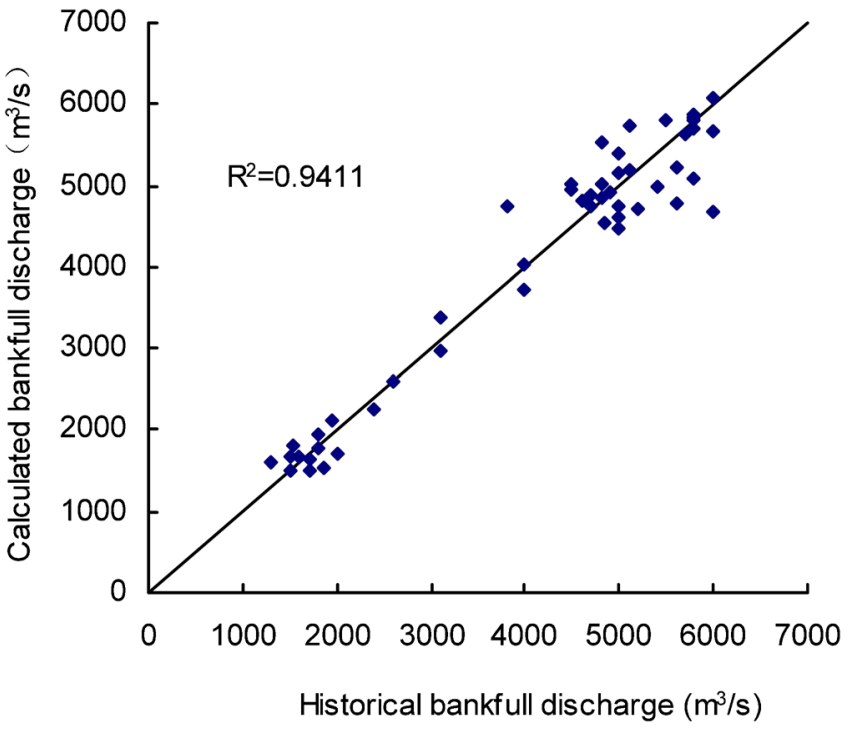

Figure 8. Comparison between calculated and historical bankfull discharge at Bayangaole.

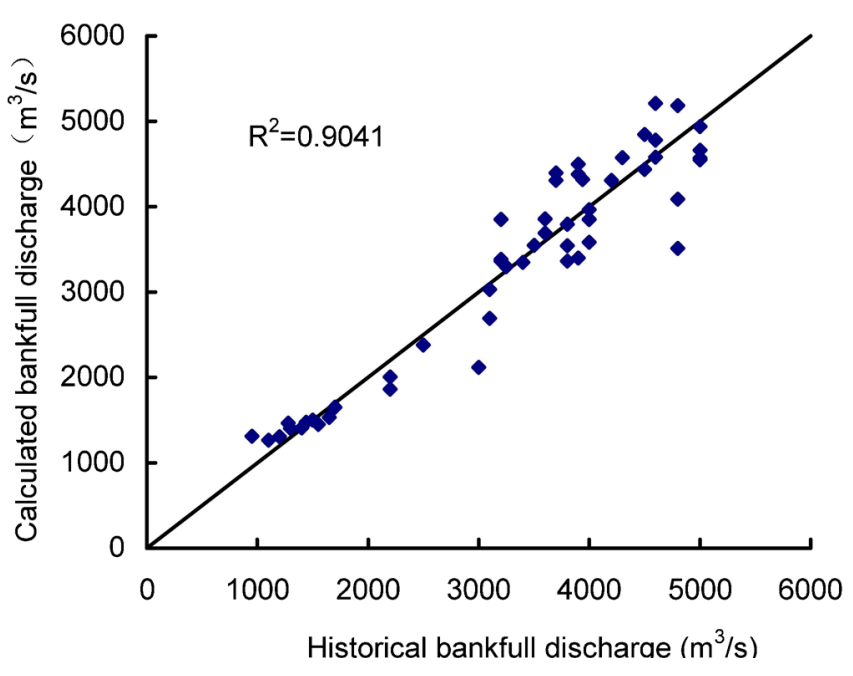

Figure 9. Comparison between calculated and historical bankfull discharge at Sanhuhekou.

adjustment and the degree of influence of the factors are also different. The influence on the lower Yellow River is delayed by approximately 5 years (Wu et al. 2007; Wu 2008) and that on the channel in Inner Mongolia is delayed by approximately 10 years.

The incoming runoff and flood peak discharge of the channel in Inner Mongolia before 1986 maintained phase equilibrium in terms of wet and dry years. This resulted in no overall change in runoff conditions, relatively steady incoming sediment coefficient, and large bankfull discharge. The years following 1986 were dry or normal-flow years for which there were trends in water and sediment conditions (figure 10). The flood peaks dropped and remained low, while the incoming sediment coefficients became larger. There was a lower chance 


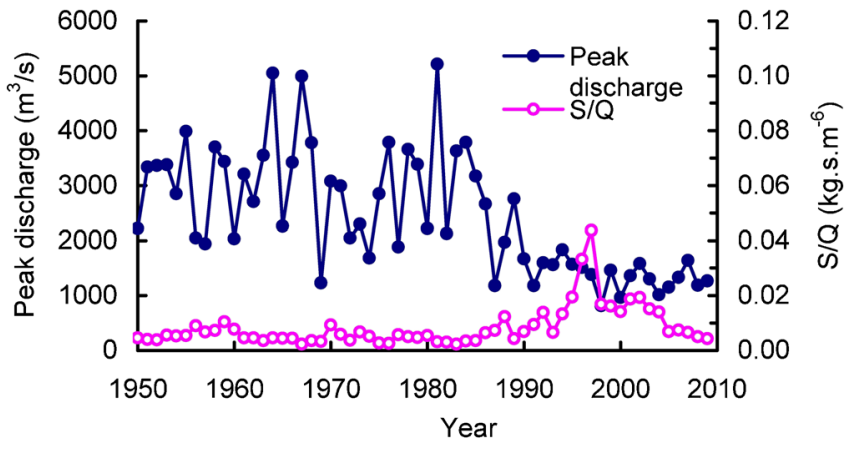

Figure 10. Historical data of flood peak discharge and incoming sediment coefficient at Bayangaole.

of overbanking and cumulative siltation occurring within the channel, leading to a reduction in bankfull discharge. It is shown in the sensitivity analysis that bankfull discharge is more sensitive to flood peak discharge than it is to the incoming sediment coefficient, suggesting that a reduction in flood peak discharge is decisive in the continuous reduction of bankfull discharge.

\section{Conclusions}

- Changes of bankfull discharge in the channel of the Yellow River in Inner Mongolia are closely correlated with flood peak discharge, incoming sediment coefficient, and the average discharge of the flood season. The fundamental reasons behind the changes in bankfull discharge since 1986 are the reduction of flood peak discharge and an increase in the incoming sediment coefficients. Bankfull discharge is more sensitive to flood peak discharge.

- The quantity of bankfull discharge is related not only to the hydraulic and sediment conditions of the current year but also to those of previous years. Single-factor analysis shows that the correlation between bankfull discharge and the 10year moving averages of water and sediment data are the most relevant, i.e., the influence of water and sediment conditions on the river reaches in Inner Mongolia exhibit a 10-year lag.

- The bankfull discharge formula for the Inner Mongolian reaches, considering both the flood peak discharge and incoming sediment coefficient, can be used to calculate and predict bankfull discharge under specific water and sediment conditions and can be applied to other sediment-laden rivers after modification.

\section{Acknowledgements}

This study was funded by the National Basic Research Program of China (973 program, no.
2011CB403303) and the National '12th Five-Year' scientific and technological support plan subject (No. 2012BAB02B03). The authors would also like to thank the reviewers for their constructive comments.

\section{References}

Biedenharn D S, Thorne C R, Soar P J, Hey R D and Watsons C C 2001 Effective discharge calculation guide; Int. J. Sedim. Res. 16(4) 445-459.

Brunsden D 1980 Applicable models of long term landform evolution; Zeitschrift Für Geomorphologie Suppl. 36 16-26.

Collier M, Webb R H and Schmidt J C 1996 Dams and rivers: A primer on the downstream effects of dams; U.S. Geological Survey Circular 1126.

Fan X L, Shi C X, Zhou Y Y and Shao W W 2012 Sediment rating curves in the Ningxia-Inner Mongolia reaches of the upper Yellow River and their implications; Quat. Int. 282 152-162.

Hou S Z 1996 Analysis on recent channel evolution characteristics on Inner-Mongolia reaches of the Yellow River; J. Yellow River 18(9) 43-44 (in Chinese).

Hou S Z and Wang P 2005 Analysis on flood-discharging index and runoff condition of channels of sections of Yellow River in Ningxia and Inner Mongolia; J. Yellow River 27(9) 24-27 (in Chinese).

$\mathrm{Hu}$ C H 2005 Variation of flow and sediment process of Yellow River and complex response of Channel; Beijing, China, China Science Press, pp. 136-137 (in Chinese).

$\mathrm{Hu}$ C H, Guo Q C, Chen J G and Chen X J 2006 Research on measures to build and maintain normal channel in lower reaches of Yellow River; J. Hydraul. Eng. 37(4) 381-388 (in Chinese).

Knighton D 1996 Fluvial forms and processes; New York, John Wiley \& Sons Inc., pp. 94-96.

Lee J S and Julien P Y 2006 Downstream hydraulic geometry of alluvial channels; J. Hydraul. Eng. 132 (12) $1347-1352$.

Leopold L B and Maddock T 1953 The hydraulic geometry of stream channels and some physiographic implications; United States Geological Survey Professional, 252p.

Li B Y, Ge Q S and Zheng J Y 2003 Channel evolution of the Yellow River in Hetao Plains in Inner Mongolia over 2000 years; Acta Geographica Sinica 58(2) 239-246 (in Chinese).

Lin X Z, Tian Y, Yi X Y and Su Y Q 2005 Response of bankfull discharge to runoff and sediment in lower Weihe River; J. Sedim. Res. 5 1-4 (in Chinese).

Liu X Y, Zhang Y F and Hou S Z 2006 Preliminary research on channel-forming mechanism of flood in alluvial sections of Yellow River; J. Yellow River 28(4) 13-15 (in Chinese).

McCandless T L 2003 Maryland stream survey: Bankfull discharge and channel characteristics of streams in the Allegheny Plateau and the valley and ridge hydrologic regions (CBFO-S03-01) U.S. Fish and Wildlife Service, Chesapeake Bay Field Office.

Nolan K M, Lisle T E and Kelsey H M 1987 Bankfull discharge and sediment transport in northwestern California; In: Proceedings of International Symposium: Erosion and Sedimentation in the Pacific Rim, Wallingford, UK, IAHS Publication 165 439-450.

Petts G E 1984 Impounded rivers: Perspectives for ecological management; New York, Wiley-Interscience. 
Petts G E and Gurnell A M 2005 Dams and geomorphologyResearch progress and future directions; Geomorphology 71(1-2) 27-47.

Qian Y Y, Wu Z and Zhu C X 1972 Preliminary analysis on maintaining effective capacity of reservoirs built along rivers with high sediment concentration; In: Proceedings of Reservoir Sediment Seminar, Zhengzhou, China (in Chinese).

Qian N, Zhang R and Zhou Z D 1987 Fluvial Process; Beijing, China, China Science Press, pp. 343-345 (in Chinese).

Qian Y Y, Cheng X W, Fu C J and Chen S D 1989 Research on Adjustment Indices of Water and Sediment of Reservoirs Built along Rivers with High Sediment Concentration; Yellow River Institute of Hydraulic Research, Zhengzhou, China (in Chinese).

Qin Y, Zhang X F, Wang F L, Yan H and Han H J 2011 Scour and silting evolution and its influencing factors in Inner Mongolian Reach of the Yellow River; J. Geogr. Sci. 21(6) 1037-1046.

Ran L S, Wang S J and Lu X X 2012 Hydraulic geometry change of a large river: A case study of the upper Yellow River; Environ. Earth Sci. 66(4) 1247-1257.

Rosgen D L 1994 A classification of natural rivers; Catena 22(3) 169-199.

Shao X J and Wang G Q 2002 The impact of upper Yellow River hydropower development on downstream fluvial processes; J. Hydroelectric Eng. 76 128-138.

Shen G Q, Zhang X H, Li Y, Shang H X and Pan X D 2000 Analysis on hydraulic and sediment variations and channel variation of lower reaches of Yellow River since 1986; J. Yellow River 22(9) 10-16 (in Chinese).

Shen G Q, Zhang Y F, Hou S Z and Shang H X 2007 Impact of water and sediment regulation by reservoirs in the upper Yellow River on Inner-Mongolia reaches; J. Sedim. Res. 1 67-75 (in Chinese).

Ta W Q, Xiao H L and Dong Z B 2008 Long-term morphodynamic changes of a desert reach of the Yellow River following upstream large reservoir's operation; Geomorphology 97 249-259.

Ta W Q, Wang H B and Jia X P 2011 Downstream fining in contrasting reaches of the sand-bedded Yellow River; Hydrol. Process. 25(24) 3693-3700.

Tayfur G and Singh V P 2011 Predicting mean and bankfull discharge from channel cross-sectional area by expert and regression methods; Water Resour. Manag. 25 1253-1267.

Wang Y C, Wang T J, Guo S H, Ma S K and Zhao H C 1999 Analysis on recent hydraulic and sediment variations in section of Yellow River in Inner Mongolia; Water Conservancy of Inner Mongolia 3 40-41 (in Chinese).
Wang S J, Fan X L and Zhao X K 2010 Changes in suspended sediment erosion-accumulation in section of the Yellow River in Ningxia and Inner Mongolia and the influencing factors; Geogr. Res. 10 1979-1987 (in Chinese).

Wang S J, Yan M, Yan Y X, Shi C X and He L 2012 Contributions of climate change and human activities to the changes in runoff increment in different sections of the Yellow River; Quat. Int. 282 66-77.

Williams G P 1978 Bankfull discharge of rivers; Water Resour. Manag. 14(6) 1141-1154.

Williams G P and Wolman M G 1984 Downstream effects of dams on alluvial rivers; U.S Geological Survey Professional Paper 1286.

Wolman M G and Miller J P 1960 Magnitude and frequency of forces in geomorphic processes; J. Geol. 68 54-74.

Wu B S 2008 Delayed response model for alluvial river; J. Hydraul. Eng. 39 680-687 (in Chinese).

Wu B S and Zhang Y F 2007 Law of along-course changing of sediment-transport of lower reaches of Yellow river and methods of calculation; J. Sedim. Res. 1 30-35 (in Chinese).

Wu B S, Xia J Q and Zhang Y F 2007 Response of bankfull discharge in lower reaches of the Yellow River to variations of incoming water and sediment; J. Hydraul. Eng. 38 886-892 (in Chinese).

Wu B S, Wang G Q, Xia J Q, Fu X D and Zhang Y F 2008 Response of bankfull discharge to discharge and sediment load in the Lower Yellow River; Geomorphology 100(3-4) 366-376.

Xu J X 2004 Research on general tendency of channel siltation of lower reaches of Yellow River under influence of human activity; J. Hydraul. Eng. 35(2) 8-16 (in Chinese).

Yao Z Y, Ta W Q, Jia X P and Xiao J H 2011 Bank erosion and accretion along the Ningxia-Inner Mongolia reaches of the Yellow River from 1958 to 2008; Geomorphology 127 99-106.

Yue C C 1995 Dictionary of River Protection of Yellow River, Zhengzhou, China; Yellow River Conservancy Press (in Chinese).

Zhang O Y, Xu J X and Zhang H W 2002 Response to flood process by adjustment of channel pattern of wandering channels of Yellow River; Acta Geographica Sinica 57 648-654 (in Chinese).

Zhao W L, Hou S Z and Wang L 2002 Influence on hydraulic and sediment variations at Toudaoguai by irrigation and adjustment from Longyangxia and Liujiaxia reservoirs; In: Proceedings of Research on Flow and Sediment Variations of Yellow River (eds) Wang G and Fan Z (Zhengzhou, China: Yellow River Conservancy Press), 2175-197 (in Chinese). 